\title{
VARIABILIDAD DE TEMPERATURA EN LA ENSENADA DE LA PAZ, B. C. S.
}

\author{
por \\ Adolfo Granados Guzmán \\ Saúl Alvarez Borrego \\ División de Oceanología \\ Centro de Investigación Científica y de \\ Educación Superior de Ensenada, B. C. \\ Espinoza No. 843 \\ Ensenada, Baja California, México
}

GRANADOS GUZMAN, A. y S. Alvarez Borrego, 1983. Variabilidad de temperatura en la Ensenada de La Paz, B. C. S. Ciencias Marinas, 9(2): 133-141.

\section{RESUMEN}

De octubre de 1980 a agosto de 1981 se obtuvieron series de tiempo de temperatura $\left(\mathrm{T}^{\circ} \mathrm{C}\right.$ ) en dos localidades de la ensenada de la Paz, B. C. S., con registradores automáticos in situ. En la boca de la ensenada las TOC mínimas se registraron en verano $\left(\sim 18^{\circ} \mathrm{C}\right)$. Estas TOC mínimas están asociadas a fluctuaciones con períodos de una semana a 20 días, y con amplitudes de $n 4{ }^{\circ} \mathrm{C}$, e indican la incidencia de aguas de surgencias del Golfo de California, con vientos del Surcste. En invierno la TOC fue muy similar en la boca y en el interior de la ensena$\mathrm{da}$, con fluctuaciones diurnas en general bajas en ambas localidades $\left(\sim 1^{\circ} \mathrm{C}\right)$. En verano la variación diurna $\left(\curvearrowleft \cdot 2.5^{\circ} \mathrm{C}\right)$ fue mayor que en invierno, debido a que las corrientes de marea mueven aguas calientes del interior somero de la ensenada y aguas frías de surgencia que han penetrado a la bahía de La Paz. En la boca de la ensenada la TOC máxima registrada fue $26.9^{\circ} \mathrm{C}$, el 27 de octubre; y la mínima fue $18.2^{\circ} \mathrm{C}$ y fue registrada el 18 de agosto.

\begin{abstract}
With in situ continuous recording thermographs, time series were generated for two locations of ensenada de $\mathrm{La} \mathrm{Paz}$ a coastal lagoon inside Bahía La Paz, B. C. S. At the mouth of the ensenada, minima $T^{\circ} \mathrm{C}$ were registered during summer $\left(18^{\circ} \mathrm{C}\right)$. These mininia were associated with variations with onc week to 20 days periods, and $\sim 4^{\circ} \mathrm{C}$ amplitudes, and are due to upwelling events in the west coast of the Gulf of California, with southeasterly winds. During winter, ToC was similar at both locations, the mouth and the interior of the lagoon, with relatively low diurnal variations in both locations $\left(\sim 1^{\circ} \mathrm{C}\right)$. During summer, diurnal variations ( $r 2.5^{\circ} \mathrm{C}$ ) were greater than during winter, due to tidal currents moving warm water from the shallow interior of the lagoon and cold upwelled water that have entered Bahia La Paz from the Gulf. At the mouth of the ensenada, maximum registered $\mathrm{T}^{\circ} \mathrm{C}$ was $26.9^{\circ} \mathrm{C}$, on October $27 \mathrm{th}$, and minimum $\mathrm{T}^{\circ} \mathrm{C}$ was $18.2^{\circ} \mathrm{C}$, registered on August 18th.
\end{abstract}




\section{INTRODUCCION}

El identificar e interpretar las frecuencias o periodicidades características de las variables de los ecosistemas debe ser uno de los objetivos centrales de la Ecología (Platt y Denman, 1975). Las propiedades del agua de mar de una laguna costera varian grandemente en función del tiempo, debido a las mareas, la dinámica del océano adyacente, los ciclos de irradiación solar, las condiciones meteorológicas, etc. Una descripción adecuada de esta variación requiere la generación de series de tiempo que además de ser relativamente largas tengan un intervalo de muestreo corto. Generalmente esto no es posible ya que se genera una cnorme cantidad de muestras que se deben analizar en el laboratorio. El contar ahora con termógrafos relativamente baratos y confiables, y capaces de generar series de tiempo automáticamente, nos permite estudiar los fenómenos que causan cambios de temperaturas ( $\mathrm{T}^{\circ} \mathrm{C}$ ). La TO C del agua de mar es una variable ecológica de gran importancia que además provee información sobre procesos físicos.

Como parte de un programa de estudio de bahías y lagunas costeras de la Península de Baja California, instalamos termógrafos en dos localizaciones de la ensenada de La Paz, B. C. S. (Fig. 1). Esto además complementó un estudio de la dinámica de esta laguna costera (Morales y Cabrera Muro, 1982). La ensenada de La Paz se localiza al

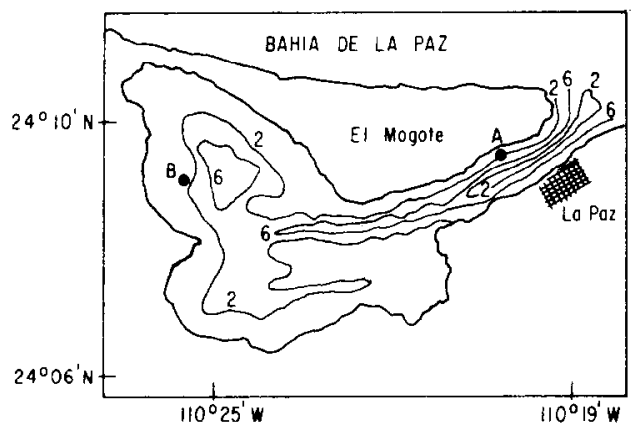

FIGURA 1. Localización de los puntos de muestreo (A y B) en la ensenada de La Paz, B. C. S. sureste de la bahía de La Paz, entre $24{ }^{\circ} 06^{\prime}$ y $24^{\circ} 10^{\prime} \mathrm{N}$, y $110^{\circ} 19^{\prime}$ y $110^{\circ} 25^{\prime} \mathrm{W}$. Es una cuenca de aproximadamente $45 \mathrm{~km}^{2}$ al nivel medio del mar. En su parte noreste tiene un par de canales paralelos que forman la boca de la laguna, con profundidades de hasta $10 \mathrm{~m}$. El canal principal se extiende por el centro de la laguna disminuyendo su profundidad a $4 \mathrm{~m}$ en la región más interna. En esta zona, tanto al noroeste como al surocste, hay dos cuencas relativamente profundas y el resto de la laguna es somero. En la región se observa un máximo de radiación solar a fines de verano y un mínimo a principios de invierno. El régimen de lluvias es en verano con un máximo en septiembre. Los vientos dominantes durante marzo-agosto son del Sur y de octubre-febrero del Noreste (Morales y Cabrera Muro 1982).

La temperatura se midió in situ con termógrafos Peabody Ryan, modelo J 90, que producen un registro analógico en papel. Se localizaron a profundidad suficiente como para permanecer $\sim 1 \mathrm{~m}$ bajo el agua en las mareas vivas más bajas. Se atendian cada dos meses y medio para cambiar papel y cada cinco meses se cambiaban también baterías. La precisión de la $\mathrm{T} O \mathrm{C}$ fue $\pm 0.5 \mathrm{O} \mathrm{C}$, y el máximo error en tiempo fue de $35 \mathrm{mi}-$ nutos para un período de 2.5 meses. Los datos fueron digitalizados manualmente, con lecturas cada hora por dos lectores independientes, y fueron procesados mediante una computadora Prime- 400 para generar los espectros de variancia y las gráficas. Las estimaciones espectrales se computaron con un algoritmo de la transformada rápida de Fourier (Jenkis y Watts, 1968).

Debido a que se utilizó un solo termógrafo en cada punto de muestreo, se perdieron partes de las series por mal funcionamiento o pérdida de los instrumentos. Del punto A (Fig. 1) se tienen datos del 27 de octubre de 1980 al 27 de febrero de 1981 , $y$ del 21 de junio al 25 de agosto de 1981 . Del punto $B$ se tienen datos del 27 de octubre de 1980 al 23 de junio de 1981 (Fig. 2). 

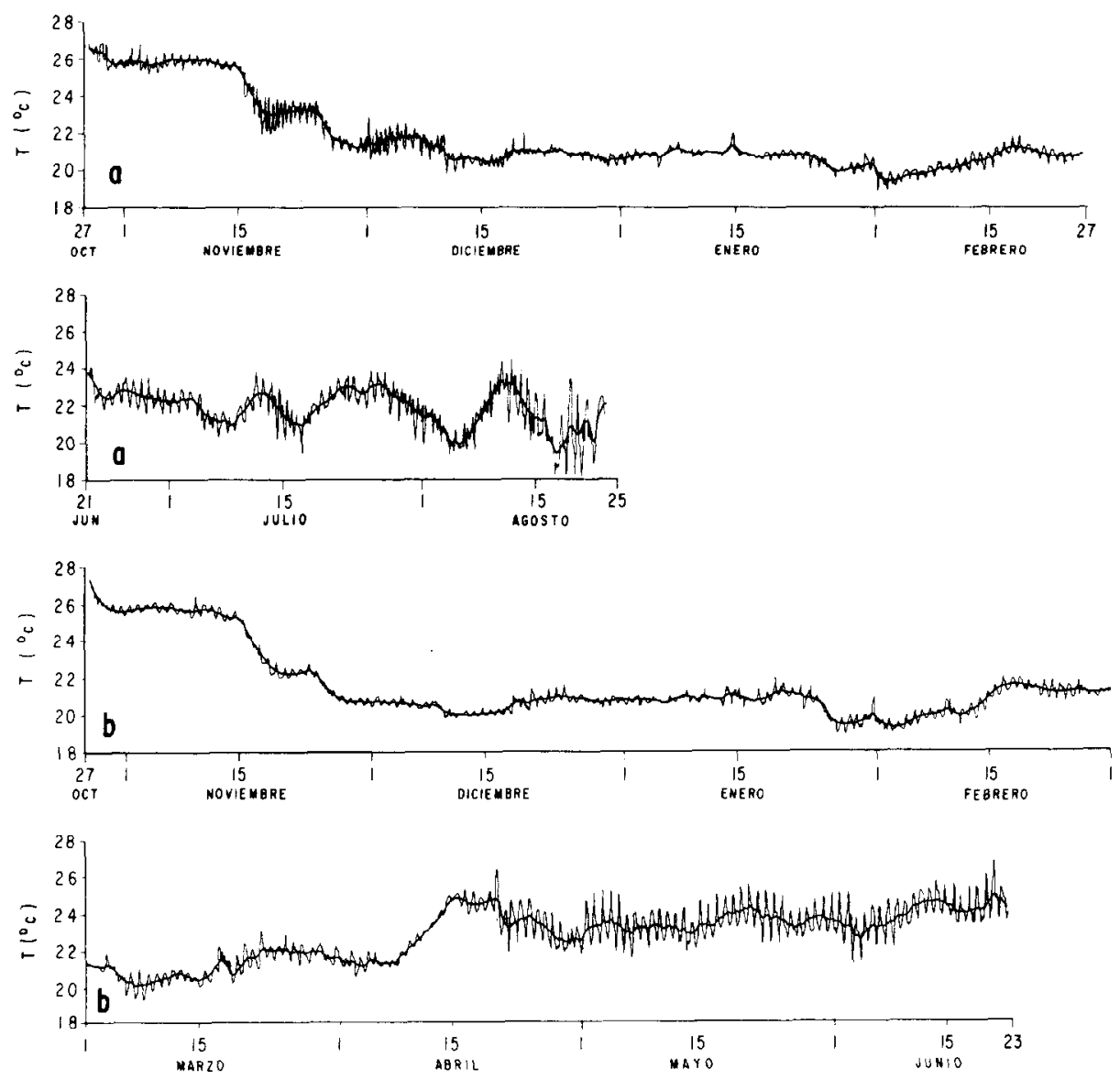

FIGURA 2. Series de tiempo de temperatura en el punto A (a) y el punto B (b).

Las temperaturas mínimas y máximas para los dos puntos fueron como sigue:

\begin{tabular}{cllll} 
& \multicolumn{2}{c}{ Mínimo } & \multicolumn{2}{c}{ Máximo } \\
Localización & Fecha & $\mathrm{T}^{\circ} \mathrm{C}$ & Fecha $\mathrm{T}^{\circ} \mathrm{C}$ \\
$\mathrm{A}$ & Agosto 18 & $18.2^{\circ} \mathrm{C}$ & Oct. 2726.9 \\
B & Enero 28 & $18.9^{\circ} \mathrm{C}$ & Oct. 2727.4
\end{tabular}

Las series de tiempo de ambas localizaciones muestran claramente una rápida disminución de la To $\mathrm{C}$ de mediados a finales de noviembre. De diciembre a principios de abril hay fluctuaciones con períodos de unos pocos días a más de un mes, y con amplitudes de hasta $\sim 3^{\circ} \mathrm{C}$. En el punto $\mathrm{B}$ (Fig. 2), la To $\mathrm{C}$ diurna promcdio sc incrementó rápidamente, aproximadamente del 8 al 15 de abril, para entrar de nuevo en condiciones de verano. Los cambios a To $\mathrm{C}$ más bajas a finales de noviembre, y a To $\mathrm{C}$ más altas en abril, posiblemente estén asociadas al cambio estacional del patrón de circulación del Golfo de California. Granados, Gallegos y Schwartzlose (1974) concluyeron que hay un patrón general de flujo superficial hacia el sur en invierno en el golfo, y hacia el norte en verano en la parte sur del golfo. El au- 
mento de To $\mathrm{C}$ en abril en la ensenada de La $\mathrm{Paz}$ posiblemente se deba a que, con vientos del Sureste, está arribando a la región sur del golfo agua subtropical superficial, misma que no se presenta con vientos del Noroeste.

Las temperaturas diurnas promedio fueron similares en ambas localizaciones de muestreo de octubre a febrero. En los tres días de junio, para los cuales se tienen registros de ambas localizaciones, la TO $\mathrm{C}$ diurna promedio fue entre 1 y $1.5{ }^{\circ} \mathrm{C}$ mayor en el punto $B$ que en el punto A. En el punto B la variación diurna fue mucho mayor de mediados de abril al final de la serie. En el punto A el registro de junio a finales de agosto muestra variaciones con períodos entre una semana y 20 días, y también con amplias fluctuaciones diurnas y semidiurnas. Además, la temperatura mínima registrada en el punto A se presentó entre el 17 y 20 de agosto $y$ fue un poco mayor que $18^{\circ} \mathrm{C}$, es decir entre 1.5 y más de $3{ }^{\circ} \mathrm{C}$ menor que las mínimas de diciembre y enero, y cerca de un $1{ }^{\circ} \mathrm{C}$ menor que la mínima de febrero. En el punto $\mathrm{A}$, las $\mathrm{T}^{\circ} \mathrm{C}$ máximas de agosto fueron más de $2{ }^{\circ} \mathrm{C}$ menores que las máximas de octubre $y$ noviembre; $y$ en el punto $B$, para el cual no tenemos datos de julio y agosto, la $\mathrm{T}{ }^{\circ} \mathrm{C}$ máxima de junio fue menor que la máxima de octubre (Fig. 2).

Los espectros de variancia de los tres registros muestran claramente una alta variancia en las bajas frecuencias, y picos claramente diferenciados en las frecuencias diurna y semidiurna (Fig. 3). La primera se debe a los cambios de alto período, desde unos
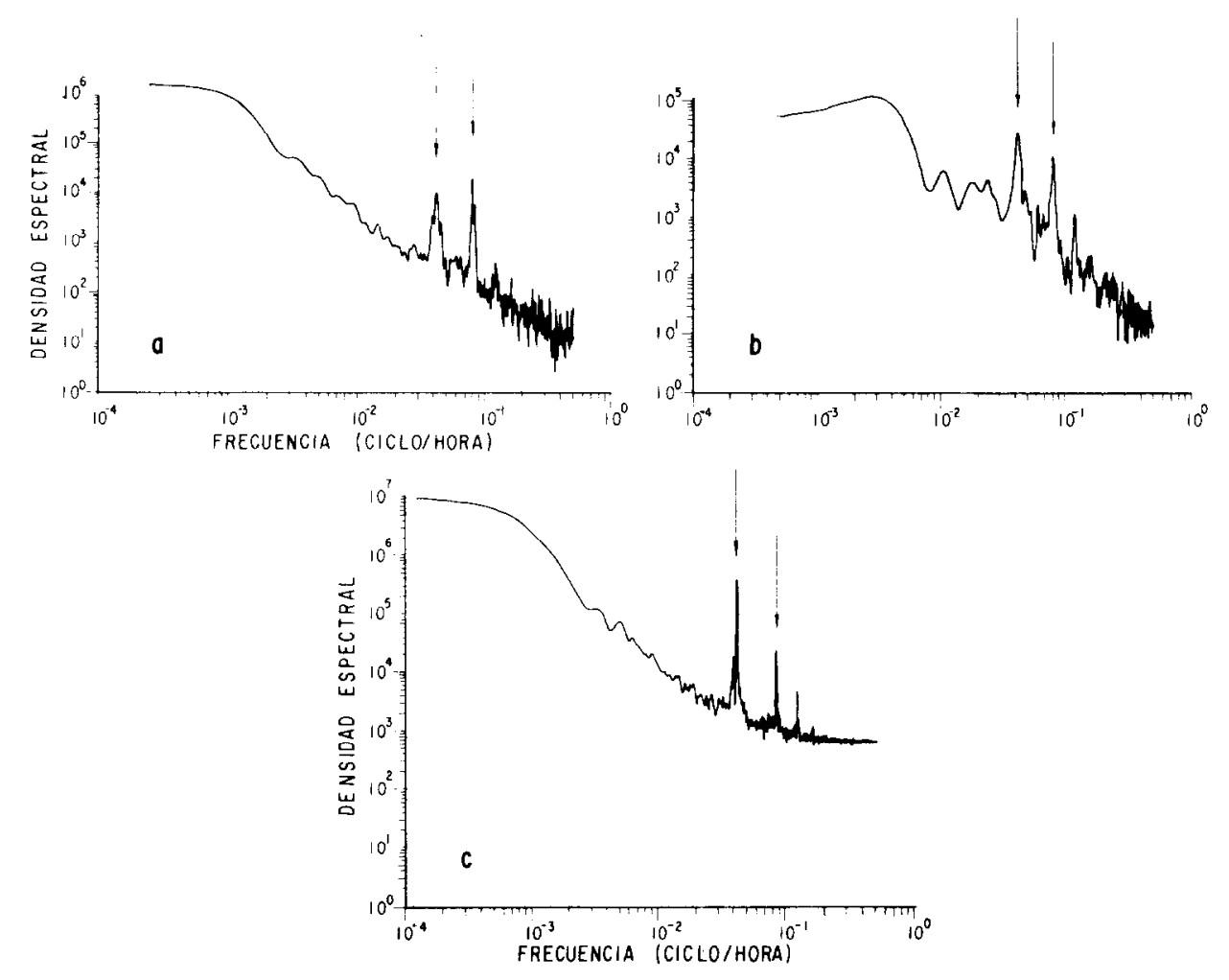

FIGURA 3. Espectros de variancia de las series de tiempo del punto A, de octubre a febrero (a) y de junio a agosto (b); y del punto $B$ (c). Las flechas indican las frecuencias diurna y semidiurna. 
pocos días hasta estacionales; y los segundos se deben principalmente a las componentes diurna y semidiurna de las mareas.

En el punto A, las fluctuaciones de TOC con períodos entre una semana y 20 días, y los bajos valores mínimos en verano, indican la presencia de aguas de surgencias (Fig. 2). Fn la costa oeste del Golfo de California ocurren surgencias durante verano, con vientos del Sureste (Roden, 1964). Alvarez Borrego y Alvarez Borrego (1982) registraron este tipo de efecto de secuencia de eventos de surgencia en series de tiempo de To $C$ de Bahía San Quintín, en el noroeste de Baja California, y también registraron TO $\mathrm{C}$ mínimas anuales en verano en la boca de esta bahía. Las altas fluctuaciones diurnas de To $\mathrm{C}$ de mediados de abril hasta el final del registro, en el punto $B$ (Fig. 2), indican que las aguas de surgencias penetran a la ensenada, mezclándose con el agua del interior. Estas altas fluctuaciones diurnas se deben a los altos gradientes horizontales de TO $\mathrm{C}$ superficial, de la bahía de La Paz hacia el interior de la ensenada, y a las corrientes de marea. En verano el agua somera del interior de la ensenada tiende a calentarse con la alta irradiación solar, mientras que en la bahía de La Paz llega agua relativamente fría de los eventos de surgencia del Golfo de California.

\section{AGRADECIMIENTOS}

Agradecemos el apoyo proporcionado por la Coordinación de Ciencias del Mar de la Universidad Autónoma de Baja California Sur y por el Centro de Investigaciones
Biológicas de La Paz en el trabajo de campo, particularmente al Biol. Edgar Amador. Agradecemos también a Araceli Armenta y Verónica Alvarez su valiosa ayuda en la lectura de los termogramas. La fase final de este trabajo recibió el apoyo de la Dirección Adjunta de Desarrollo Científico del CONACYT, mediante proyecto No. PCCBNA020120

\section{BIBLIOGRAFIA}

ALVAREZ BORREGO, J. y S. Alvarez Borrego 1982. Temporal and spatial variability of Temperature in two coastal lagoon. CalCOFI Rep., Vol. XXIII: 188-197.

GRANADOS GALLEGOS, J. L. y R. A. Schwartzlose. 1974. Corrientes superficiales en el Golfo de California. En: Memorias del V Congreso Nacional de Oceanografía. Escuela de Ciencias Marítimas del Instituto Tecnológico de Monterrey, Guaymas, Son.

JENKINS, G.M. y D.G. Watts. 1968. Spectral analysis and its applications. Holden-Day, San Francisco, 525 p.

MORALES, F. R. y H. R. Cabrera Murn. 1982. Aplicación de un modelo numérico unidimensional a la ensenada de La Paz, B. C. S. Ciencias Marinas (Méx) 8 (2): 69-89.

PLATT, T. y K. L. Denman. 1975. Spectrol analysis in ecology. Ann. Rev. Ecolugy and Systematics 6: 189-210.

RODEN, G. I. 1964. Oceanographic aspects of the Gulf of California. En: Tj. H. van Andel y G. G. Shor Jr. (Editores) Marine Geology of the Gulf of California: A symposium. Am. Assoc. Pet. Geol., Mem., 3: 30-58. 
TEMPERATURE VARIABILITY IN ENSENADA DE LA PAZ, B.C.S.

\author{
by \\ Adulfo Granados Guzmán \\ and \\ Saúl Alvarez Borrego \\ División de Oceanología \\ Centro de Investigación Científica y de \\ Eđucación Superior de Ensenada, B. C. \\ Espinoza No. 843 \\ Ensenada, Baja California, México
}

GRANADOS-GUZMAN, A. and S. Alvarez-Borrego, 1983. Temperature variability in Ensenada de La Paz, B. C. S. Ciencias Marinas, $9(2): 133-141$,

\section{INTRODUCTION}

Identifying and interpreting the characteristic frequencies or periodicities of the ecosystem's variables should be one of the central goals of the discipline of ecology (Platt and Denman, 1975). In a coastal lagoon, seawater properties have large variations due to tidal currents, the adjacent ocean dynamics, the solar radiation cycles, the meteorological conditions, etc. An adequate description of these variations requires the generation of time series. Ideally, time series should be at least one year long, to roughly describe seasonal changes; and sampling intervals should be short (i.e.: one hour). Usually this is not possible, because an enormous amount of samples has to be collected and analyzed manually. With relatively cheap and reliable thermographs able to automatically generate time series, it is possible to study the natural phenomena that cause temperature $(\mathrm{TOC}$ ) changes. Sea water T $^{\circ} \mathrm{C}$ is a very important ecological variable that provides informationon physical processes.

We installed thermographs in two locations of ensenada de La Paz, B.C.S. (Fig. 1), as part of a program to study the bays and coastal lagoons of the Baja California Peninsula. Morales and Cabrera-Muro (1982) studied the dynamics of Ensena-

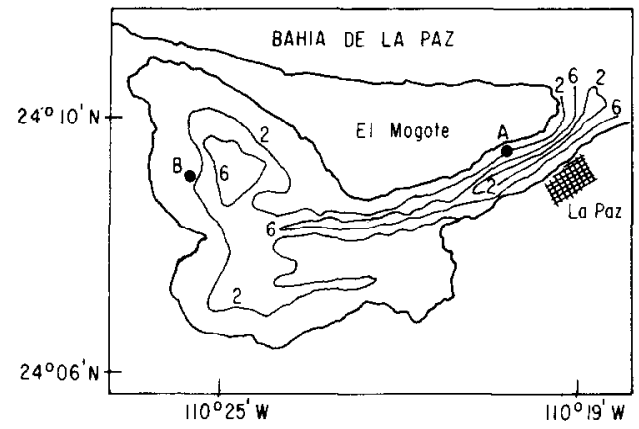

FIGURA 1. Location of the sampling points (A and B) in the Ensenada de La Paz, B. C. S.

da de La Paz. Our study adds information on it. Ensenada de la Paz is a coastal lagoon at the southeastern part of Bahía de La Paz, at $24^{\circ} 06^{\prime}$ and $24^{\circ} 10^{\prime} \mathrm{N}$, and $110^{\circ} 19^{\prime}$ and $110^{\circ} 26^{\circ} \mathrm{W}$. It is a basin of approximately $45 \mathrm{~km}^{2}$ at mean sea level. The mouth of the lagoon, located at the northeastern region, has two parallel channels, with depths up to $10 \mathrm{~m}$. The main channel runs through the middle of the lagoon, decreasing its depth to $4 \mathrm{~m}$ at the extreme. There are two relatively deep basins, at the northwestern and southwestern regions respectively, and the rest of the lagoon is shallow. Solar radiation is maximum at the end of summer and $\mathrm{mi}^{-}$ nimum at the beginning of winter. Summer 
is the rainy season, with a maximum in September. During March-August dominant winds are from the South, and from the Northeast during October-February (Morales and Cabrera-Muro, 1982).

Temperature was measured in situ with Peabody Ryan, J. 90, thermographs, which produce an analog record on paper. They were located deep enough to remain $\sim 1 \mathrm{~m}$ under water even at the lowest spring tides. Every 2.5 months paper was changed, and every 5 months also batteries were changed. Precision for $\mathrm{T}^{\circ} \mathrm{C}$ was $\pm 0.5^{\circ} \mathrm{C}$ and the maximum error in time was $35 \mathrm{mi}$ nutes for a 2.5 months period. Data were digitized manually, with readings every hour, by two independent readers. Data were then input to a Prime-400 computer to generate variance spectra and graphs. Spectral estimates were computed with a fast Fourier transform algorithm (Jenkins and Watts, 1968).

We only used one instrument per sampling site at a time. Thus, due to malfunction or lost of instruments, we lost part of the time series. From point A (Fig. 1) we have data from October 27th, 1980, through February 27th, 1981; and from June 21st through August 25th, 1981. From point $B$ we have data from October 27th, 1980, through June 23th, 1981 (Fig. 2).

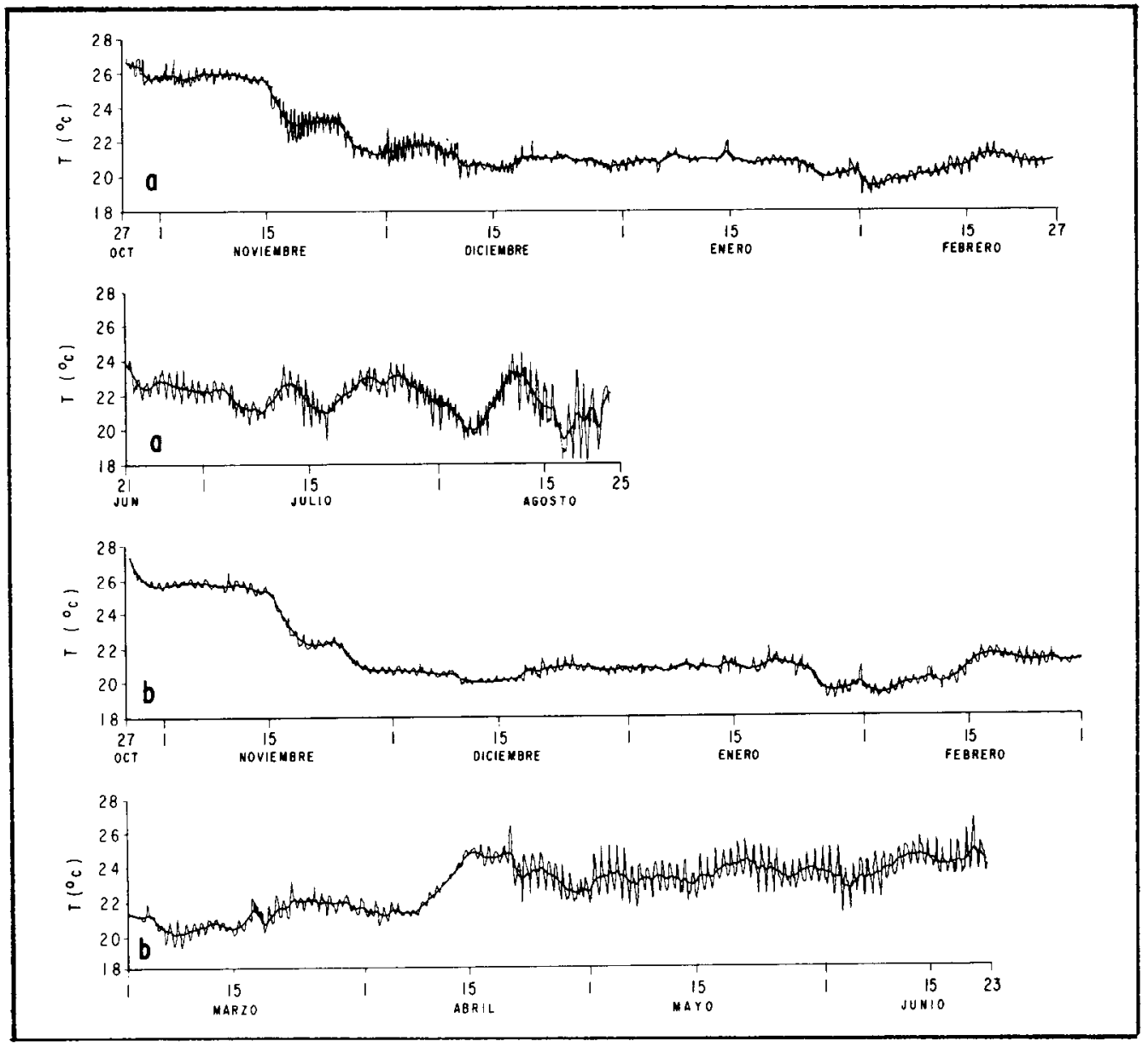

FIGURE 2. Temperature time series from point $A(a)$ and point $B(b)$. 
locations were:

Minima and maxima $\mathrm{T}^{\circ} \mathrm{C}$ for both

\begin{tabular}{cccccc}
\multicolumn{3}{c}{ Minimum } & \multicolumn{2}{c}{ Maximum } \\
Location & Date & T ${ }^{\circ} \mathrm{C}$ & Date $\quad$ T $^{\circ} \mathrm{C}$ \\
A & August 18th & 18.2 & Oct. 27th 26.9 \\
B & January 28th & 18.9 & Oct. 27th 27.4
\end{tabular}

Time series from both locations show clearly a rapid decrease of $\mathrm{T}^{\circ} \mathrm{C}$ from the middle to the end of November. From December to the beginning of April, there are fluctuations with periods of few days to more than a month, and with amplitudes up to $\sim 3^{\circ} \mathrm{C}$. At location B (Fig. 2), the diurnal mean $\mathrm{TO}^{\mathrm{O}} \mathrm{C}$ increased rapidly from April 8th through 15 th, to enter into summer conditions. To $\mathrm{C}$ changes, to lower values at the end of November and to higher values in April, are possibly associated to the seasonal change of the circulation regime in the Gulf of California, Granados-Gallegos and Schwartzlose (1974) concluded that there is a general southward surface flow during winter in the Gulf, and northward flow during summer in the southern Gulf. The To $\mathrm{C}$ increase in April in Ensenada de La Paz possibly is caused by arrival of subtropical surface water to the southern region of the Gulf, with southeasterly winds. This subtropical water is not present in the southern region of the Gulf with northwesterly winds.

Mean diurnal $\Gamma \circ \mathrm{C}$ were similar in both locations from October through February. During the three days of June for which we have data from both locations, mean diurnal $\mathrm{T}^{\circ} \mathrm{C}$ was 1 to $1.5^{\circ} \mathrm{C}$ greater at point $B$ than at point $A$. At point $B$, the diurnal variation was greater from the middle of April to the end of the series. The thermogram from point $A$, from June through the end of August, shows variations with periods of a week to 20 days, and also with large diurnal and semidiurnal fluctuations. Minimum $\mathrm{T}^{\circ} \mathrm{C}$ at point $\mathrm{A}$ was registered between the 17th and 20th of August, and was a little greater than $18^{\circ} \mathrm{C}$. This minimum $T^{\circ} \mathrm{C}$ was 1.5 to $3^{\circ} \mathrm{C}$ lower than the December and January minima, and $1{ }^{\circ} \mathrm{C}$ lower than the February minimum. At point
A, maxima $\mathrm{T}^{\circ} \mathrm{C}$ during August were more than $2^{\circ} \mathrm{C}$ lower than the October and November maxima. At point $B$, from which we have no data for July and August, maximum ${ }^{\mathrm{T}}{ }^{\circ} \mathrm{C}$ in June was lower than the maximum of October (Fig. 2).

Variance spectra of the three thermograms clearly show high variance at the low frequencies, with distinct peaks at the diurnal and semidiurnal frequencies (Fig. 3). The low frequency high variance is due to To $\mathrm{C}$ changes with large periods, from few days to seasonal; and the diurnal and semidiurnal peaks are mainly due to the tides.

At point $A$, TOC fluctuations with periods between a week and 20 days, and the summer low minima, indicate the presence of upwelling waters (Fig. 2). With southeasterly winds during summer, upwelling events occur in the west coast of the Gulf of California (Roden, 1964). AlvarezBorrego and Alvarez-Borrego (1982) registered this type of effect caused by the sequence of upwelling events in $\mathrm{T}^{\circ} \mathrm{C}$ time series from Bahia San Quintin, in the northwestern coast of Baja California. They also registered annual ${ }^{\circ} \mathrm{C}$ minima in summer at the mouth of this bay. High To $C$ diurnal fluctuations, from the middle of April to the end of the thermogram from point B (Fig.2), indicate that upwelling waters entered the Ensenada and mixed with the interior water. These high diurnal fluctuations are caused by high horizontal gradients of surface $\mathrm{T}^{\circ} \mathrm{C}$, from Bahia de La Paz to the interior of the Ensenada, and by tidal currents. During summcr, the shallow interior water of the Ensenada warms up due to high solar radiation, while relatively cold water arrives to Bahia de $\mathrm{La} \mathrm{Paz}$ from the upwelling. events in the Gulf of California. 


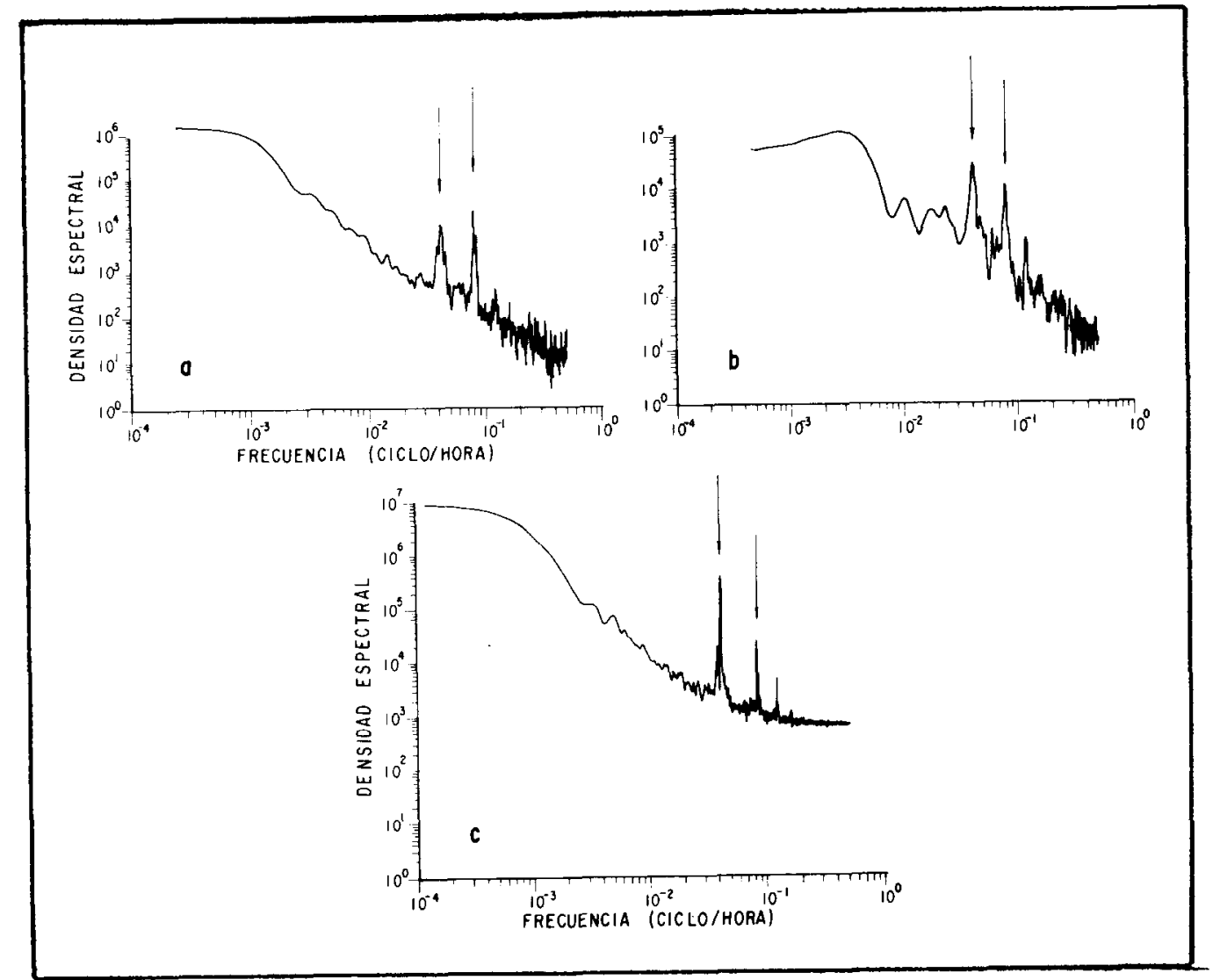

FIGURE 3. Variance spectra for the time series from point A, October-February (a) and June-August (b); and from point $\mathrm{B}(\mathrm{c})$. Arrows indicate the diurnal and semidiurnal frequencies. 